\title{
Miasteczka Tyzenhauzowskie - świadectwo kultury przestrzennej końca XVIII w. we współczesnym krajobrazie miejscowości (Krynki, Dąbrowa Białostocka, Sokółka) ${ }^{1}$
}

\author{
Dorota Gawryluk \\ e-mail:d.gawryluk@pb.edu.pl \\ Politechnika Białostocka, Wydział Budownictwa i Inżynierii Środowiska, Katedra Ochrony \\ i Ksztattowania Środowiska, Zespót Dydaktyczny Architektury Krajobrazu \\ Bialystok University of Technology, Facultyof Civil and Environmenatl \\ Engineering, Landscape Architecture Teaching Team
}

\begin{abstract}
Streszczenie: Działalność Antoniego Tyzenhauza (podskarbiego litewskiego z czasów Stanisława Augusta oraz starosty grodzieńskiego) pod koniec XVIII w. miała na celu aktywizację gospodarczą płn-wsch. części Rzeczpospolitej. Z jego inicjatywy powstało około 50 manufatur w różnych miejscowościach w regionie Grodna. W stosunku do wybranych miasteczek (m.in. Krynek, Dąbrowy Białostockiej i Sokółki) efektem działalności Tyzenhauza była także zmiana ich formy przestrzennej. Miasteczka zyskały regularne plany o geometrycznej kompozycji urbanistycznej. Dominanty architektoniczne, wpisane w ich strukturę potwierdzały klasyczną kompozycję przestrzenną. Kultura przestrzenna planów końca XVIII w., pomimo burzliwych losów miasteczek, przetrwała i stanowi istotną cechę ich współczesnej tożsamości. Artykuł jest poświęcony zachowaniu czytelności kompozycji architektoniczno-urbanistycznej końca XVIII w. we współczesnym krajobrazie Krynek, Dąbrowy Białostockiej i Sokółki.
\end{abstract}

Słowa kluczowe: miasteczka tyzenhauzowskie, Krynki, Dąbrowa Białostocka, Sokółka, krajobraz miasteczka

\section{Wstęp}

Zagadnienie miast idealnych jest szeroko dyskutowane w literaturze tematu dotyczącej historii budowy miast europejskich i innych kontynentów. Funkcjonuje już ustalony kanon podstawowych przykładów miast zrealizowanych na kanwie koncepcji miasta idealnego, lecz wątki te nadal są przez badaczy analizowane i wiedza rozbudowywana o kolejne przykłady realizacji z różnych epok historycznych ${ }^{2}$. Na tym tle ciekawym zagadnieniem wydaje się niedoceniony dotychczas temat miast zrealizowanych z inicjatywy Antoniego Tyzenhauza, działającego z ramienia króla Stanisława Augusta Poniatowskiego pod koniec XVIII wieku w ekonomii grodzieńskiej ówczesnej Rzeczpospolitej.

W Europie, już w II poł. XVIII wieku, rozwijano idee tworzenia ośrodków produkcyjnych, w których poza uwarunkowaniami technologicznymi i kompozycyjnymi zwracano także uwagę na zapewnianie dobrych warunków 
życia pracownikom ${ }^{3}$. Koniec wieku XVIII w historii budowy miast zaowocował rozwiązaniami przestrzennymi opartymi w wielu przypadkach na powiązaniu reprezentacyjności kompozycji barokowej z uporządkowaniem i klarownością koncepcji renesansowych miast idealnych. Feudalne ambicje właścicieli były wówczas zaspokajane poprzez upodabnianie należących do nich ośrodków, do świetnych wzorów rozległych założeń rezydencjonalnych, z jednoczesnym wpisaniem w ich układ przestrzenny obiektów, które przynosiłyby profity ${ }^{4}$. Często nowe lub przebudowywane miejscowości, programowo planowano, jako osady produkcyjne. Rozmieszczenie w nich zakładów rzemieślniczych, manufaktur a wreszcie małych fabryk i obiektów im towarzyszących z jednej strony warunkowane było korzystną dla procesu produkcji lokalizacją, z drugiej zaś stanowiło istotny element kompozycji przestrzennej całej miejscowości potwierdzając jej walor (wymiar) estetyczny, a w wybranych przypadkach także symboliczny.

\section{Działalność Antoniego Tyzenhauza}

Na szerokim tle działań mających na celu tworzenie preindustrialnych miasteczek o zdefiniowanym klasycznym układzie urbanistycznym powstających w II poł. XVIII w. w Europie i Rzeczpospolitej, wartą podkreślenia wydaje się działalność Antoniego Tyzenhauza. W latach 1765-1780, zarządzał on a następnie administrował ekonomią grodzieńską. Pod jego kuratelą znajdowały się 22 miasta z obszaru ekonomii grodzieńskiej (15) i powiązanej z nią wówczas administracyjnie i gospodarczo ekonomii olickiej $(7)^{5}$. Koncepcją Tyzenhauza było, aby każdy klucz stanowiący podrzędną jednostkę ekonomii, posiadał swoje miasto ${ }^{6}$.

Działalność gubernatora prowadzona z ramienia króla Stanisława Augusta Poniatowskiego, miała na celu zaktywizowanie gospodarcze historycznie niedoinwestowanego regionu północnych rubieży Rzeczpospolitej. Rozwój gospodarczy miał przynosić profity państwu i jednocześnie wpłynąć pozytywnie na stan ekonomiczny

3 L. Benevolo, S. Kostof, s. 196-197; P. Szafer, s. 77; Standard owych warunków był różnie definiowany, np. Claud Nicolas Ledoux w projekcie miasta Chaux (1775) kierował się raczej potrzebami duchowymi i społecznymi niż fizycznymi robotników. W mieście zostały zaprojetowane następujące obiekty: budynek Placifere - rozstrzyganie konfliktów, Oikema - świątynia Miłości, Temple of Memoire - Świątynia Pamięci Miasteczko zaprojektowane na planie regularnego owalu miało stanowić centrum większego obszaru, w którym powiązania przestrzennofunkcjonalne dotyczyły sąsiedztwa lasu stanowiącego źródło drewna oraz kanału, którego nurt był wykorzystywany w produkcji sol z odparowywanej wody. Plan osady miał bardzo sformalizowany kształt dwóch liter D stykających się ze sobą. Z centrum wychodziły promieniście rozłożone aleje, natomiast droga obwodowa wyznaczała granice miasta w przestrzeni. Dyspozycja urbanistyczna miasta odpowiadała także hierarchii społecznej (trzy warstwy) i zarządzaniu ośrodkiem (w centrum administracja w bezpośrednim sąsiedztwie warzelni soli). Koncepcja ta została zrealizowana tylko w połowie, pomimo to cechy zdefiniowanej kompozycji przestrzennej są w niej wyraźnie czytelne.

4 J. Słodczyk, s. 270; T. Wróbel, s. 235, 238, T. P. Szafer, s. 47-82; W Rzeczpospolitej końca XVIII wieku realizowane koncepcje urbanistyczne dotyczące zarówno miast prywatnych, jak i królewskich, ze względu na cechy kompozycji przestrzennej można podzielić na rozplanowania radialne (promieniste) oraz prostokątne. Wybrane przykłady potwierdzające tę klasyfikację przywołuje Tadeusz Szafer, Wróbel i Słodczyk przytaczają je także w swoich pracach dotyczących historii urbanistyki.

Prywatny Katerburg (ok. 1780), czy pozostający w administracji królewskiej Korzec rozbudowany na bazie manufaktury czasów stanisławowskich to przykłady planów centralnych z promieniście prowadzonymi ulicami akcentowanymi w głównych osiach. Radialnie rozplanowane nowe osiedla przemysłowe powstały także w powiecie opolskim. Schodnia nad Małą Panwią (1775), czy Kup (1780) to miejscowości o koncentrycznym układzie, w których obszerne place centralne (np. w Schodni miał średnicę ok. 80 m) definiują promienisty plan.

Rozplanowanie prostokątne dawało regularny układ powiązany z klasyczną kompozycją urbanistyczną. Zapewniało miastom powiązania osiowe i widokowe części rezydencjonalnej z pozostała miejską, w tym często o charakterze produkcyjnym. W większości wypadków dotyczyło prywatnych miast, których właściciele zabiegali zarówno o walory estetyczne kompozycji przestrzennej miejscowości powiązanej z ich siedzibą, jak również o ich rozwój gospodarczy dający dochód właścicielowi. Nowy Dwór n. Narwią (1797), będący ośrodkiem przemysłu włókienniczego, czy pozostające w administracji królewskiej Kozienice (1782) z charakterystycznym rozległym rynkiem (ok. $540 \times 175$ m) to przykłady rozplanowania prostokątnego. Miasto prywatne, w których rozwinięto tę kompozycję przestrzenną to np. Krystynopol, w którym rynek pełnił także rolę avant-cour przed siedzibą właścicieli. Liczne miasta rezydencjonalne zrealizowano stosując powiązania osiowo-widokowe ze względu na podkreślenie ich reprezentacyjnego charakteru (Rydzyna, Andrychów, Kock, Siedlce, Radzyń Podlaski czy Czerniejewo). Dominantom architektonicznym w postaci ratuszów miejskich, poza ich funkcjami administracyjną i kompozycyjną przypisywano także jako wiodącą - handlową, zapewniającą profity właścicielom miast (Białystok, Siemiatycze...). Dążąc do szybszego rozwoju produkcji rzemieślniczej zaczęto sprowadzać wykwalifikowanych rzemieślników z Niemiec.

5 P. Borowik, lle miasteczek naprawdę istniało w ekonomii grodzieńskiej w okresie zarządu Antoniego Tyzenhauza?, [w:] Małe Miasta. Historia i Współczesność, M. Zemło (red.) Supraśl 2001, tom I, s. 75-77; P. Borowik, Rozplanowanie miasteczek ekonomii grodzieńskiej w czasach Antoniego Tyzenhauza, [w:] Małe Miasta. Przestrzenie, M. Zemło (red.) Supraśl 2003, tom III, s. 35-39; Współcześnie omawiane tereny położone są na pograniczu polsko-litewsko-białoruskim.

6 J. Wiśniewski, Osadnictwo wschodniej białostocczyzny. Geneza, rozwój oraz zróżnicowanie I przemiany etniczne, [w:] Acta Baltico-Slavica, t. 11, Wrocław 1977, s. 48; P. Borowik, Ile miasteczek..., s. 75-79; Pod zarządem Tyzenhauza pozostawały: w ekonomii grodzieńskiej: Grodno, osada Kunsztów nad Łosośną pod Grodnem, Dąbrowa, Janów, Jeleniweo, Jeziory, Korycin, Krasnopol, Kuźnica, Krynki, Lipsk, Łunna, Mosty, Nowy Dwór, Odelsk, Skidel, Sokólka, Suchowola, Szczebra, w ekonomii olickiej: Olita (Alytus - Litwa) i współczesne wsie Kwasówka vel Pohorany (Kvasovka - Białoruś), Bartniki (Bartninkai - Litwa), Pojtwonie (Pajavonis - Litwa), Krakopol (Krokilaukis - Litwa) oraz w powiązanej z nią ekonomii szawelskiej: Mieszkucie, Skajzgierz. 
miasteczek oraz całego regionu. Wznoszenie manufaktur Tyzenhauz łączył z przebudową miejscowości (o ile pozwalały na to warunki) i nadawaniem przestrzeni ośrodków nowej jakości urbanistycznej. W wielu przypadkach zarzucano mu zbyt duży rozmach i kosztowność inwestycji, wręcz megalomanię, nieodpowiednią w stosunku do skali prowincjonalnych miejscowości, w których były prowadzone.

W literaturze tematu dotyczącej historii urbanistyki, czy też historii gospodarczo-politycznej Polski najczęściej przywoływanym przykładem świadczącym o działalności Antoniego Tyzenhauza jest Kunsztów koło Grodna ${ }^{7}$.

Wśród miasteczek, którymi zarządzał Tyzenhauz największym przemianom przestrzennym poddano te, które w latach 60. i 70. XVIII wieku nawiedził pożar. Zniszczenia dawały możliwość wprowadzenia nowej struktury urbanistycznej, jednocześnie działania budowlane były intensyfikowane w celu zatrzymania na miejscu mieszkańców. Wykorzystywano typowe projekty opracowane dla różnych skali miejscowości (założenia dworsko-ogrodowe stanowiące siedzibę administracji guberni) oraz ich wyposażenia w obiekty o zdefiniowanych funkcjach (tj. dom felczera, austeria, zajazd...) $)^{8}$. Plany urbanistyczne, odpowiadające kryteriom estetycznym epoki, wzorowano na kompozycjach łączących cechy osiowych rozwiązań barokowych i koncentryczno-radialnych układów miast idealnych doby renesansu. W strukturze miejscowości celowo zakładano powiązania widokowo-przestrzenne głównych placów (rynków) i obiektów dominant (świątyń) także w związku z lokalizacją folwarku będącego siedzibą ośrodka administracji. Zgeometryzowane, ideowe schematy planów musiały być poddawane korekcie ze względu na uwarunkowania topograficzne.

Pomimo zmian w zabudowie i strukturze przestrzennej miejscowości, które zaszły przez ponad dwieście lat, współcześnie nadal można odczytać w krajobrazie wybranych miasteczek utrwalone układy urbanistyczne (lub ich fragmenty) oraz powiązania widokowe. Najbardziej wartościowe cechy kompozycji przestrzennej zostały zachowane w ocenie autorki w Krynkach, Dąbrowie Białostockiej i Sokółce (obecnie w województwie podlaskim).

\section{Cel badań}

Celem badań jest prezentacja zachowania czytelności układu kompozycyjnego miasteczek (Krynki, Dąbrowa Białostocka i Sokółka) bazującego na XVIII-wiecznym schemacie, łączącym cechy założeń rezydencjonalnych z geometrycznie uporządkowaną strukturą miast idealnych, we współczesnym krajobrazie tych ośrodków. Kompozycja nadana prowincjonalnym miejscowościom północnych rubieży Rzeczpospolitej, świadczy o kulturze urbanistycznej końca XVIII wieku, odpowiadającej ideowo rozwiązaniom realizowanym w tym czasie w Europie i centralnej Polski. Działania mające na celu aktywizację gospodarczą regionu, zaowocowały jednocześnie wprowadzeniem w strukturę miejscowości układów przestrzennych odpowiadających kryteriom estetycznym epoki. Prowincjonalne miasteczka zyskały znamiona ośrodków o planach wzorowanych na przedprzemysłowych miastach okresu Klasycyzmu.

\section{Stan badań}

Dotychczasowe badania odnoszące się do działalności Antoniego Tyzenhauza, prowadzone przez przedstawicieli różnych dyscyplin naukowych, dotyczyły szerokiego zakresu zagadnień. Mieściły się wśród nich tematy związane z historią uwarunkowań polityczno-społecznych i ekonomiczno-gospodarczych północnej części przedrozbiorowej Rzeczpospolitej (Dobroński, Maroszek, Borowik), monografie wybranych miejscowości (Bach, Postołowicz), historia przestrzennego rozwoju wybranych miasteczek, a wśród nich: Krynek, Sokółki i Dąbrowy

7 J. Słodczyk, s. 273; T. Wróbel, s. 257-259; Został on zrealizowany, jako osada fabryczna, na gruntach królewszczyzny. Przewidziano w nim 14 manufaktur, zabudowę dla robotników (budynki mieszkalne, administracyjne, usługowe i kultowe), teren na targowisko. Kompozycja urbanistyczna została wpasowana w klasyczną formę systemu okrągłych placów wraz z radialnymi ulicami. Liczba ulic była przy każdym placu parzysta - 6 lub 8. Geometryczna regularność skupienia ulic i budynków, perspektywy podkreślone zamknięciami architektonicznymi lub krajobrazowymi potwierdzały kunszt klasycznej kompozycji urbanistycznej wywodzącej się od wzorów osiowych barokowych rezydencji i renesansowych schematów miast idealnych.

8 T. Sulerzycka, Katalog rysunków z Gabinetu Rycin Biblioteki Uniwersyteckiej w Warszawie, cz. 2, Miejscowości różne. Rysunki architektoniczne, dekoracyjne. Plany i widoki z XVIII i XIX wieku, Warszawa 1969; P. Borowik, Rozplanowanie I zabudowa Sokótki w XVII-XVIII wieku, [w:] Małe Miasta. Między Tradycją a Wyzwaniem Przeszłości, M. Zemło (red.) Supraśl 2002, tom II, s. 32 
Białostockiej (Borowik, Słodczyk, Szafer, Wróbel), czy też badania dotyczące folwarków wraz z komponowanymi założeniami ogrodowymi (Bończak-Kucharczyk, Maroszek, Ciołek).

Rozwój przestrzenny Krynek od końca XVIII wieku został w literaturze tematu opisany najszerzej spośród grupy wybranych miasteczek. Przemysław Borowik precyzyjnie omówił rysunek „Planty miasta JKM oraz Dworu Krynek", którego autorstwo z 1780 roku przypisywane jest Józefowi de Sacco ${ }^{9}$. Zgeometryzowany rysunek ma wyraźne konotacje formalne z planami miast idealnych. Wg opinii Borowika jest koncepcyjnym schematem planu nieuwzględniającym uwarunkowań topograficznych miejsca, który mógł się stać podstawą odbudowy Krynek po pożarach z lat 70. XVIII w. Rysunek przedstawia miasteczko położone po dwóch stronach rzeki. Z jednej strony doliny znajduje się część o układzie centralnym, której środek stanowi sześcioboczny rynek z ulicami promieniście od niego odchodzącymi oraz jedną ulicą obwodową. W tej części przewidziano lokalizację cerkwi i synagogi kompozycyjnie powiązanych z foremnym rynkiem, przy którym przewidziano także ratusz i kramy miejskie. Po drugiej stronie rzeki zaplanowano lokalizację folwarku z ogrodami (siedzibę administracji guberni) powiązanego osią kompozycyjną z prostokątnym rynkiem, a tego znowu z dominantą budowli kościoła. Brak dotychczas pośrednich przekazów mówiących o tym jaki zakres planu został zrealizowany.

Tadeusz Szafer przywołując przerys planu części "starego miasta” Krynek z 1899 roku podkreśla, że mimo przekształceń przestrzennych wynikających zapewne z korekty planu idealnego do zastanych warunków topograficznych, została zachowana czytelność koncepcji sześciobocznego rynku i promieniście rozchodzących się od niego ulic ${ }^{10}$.
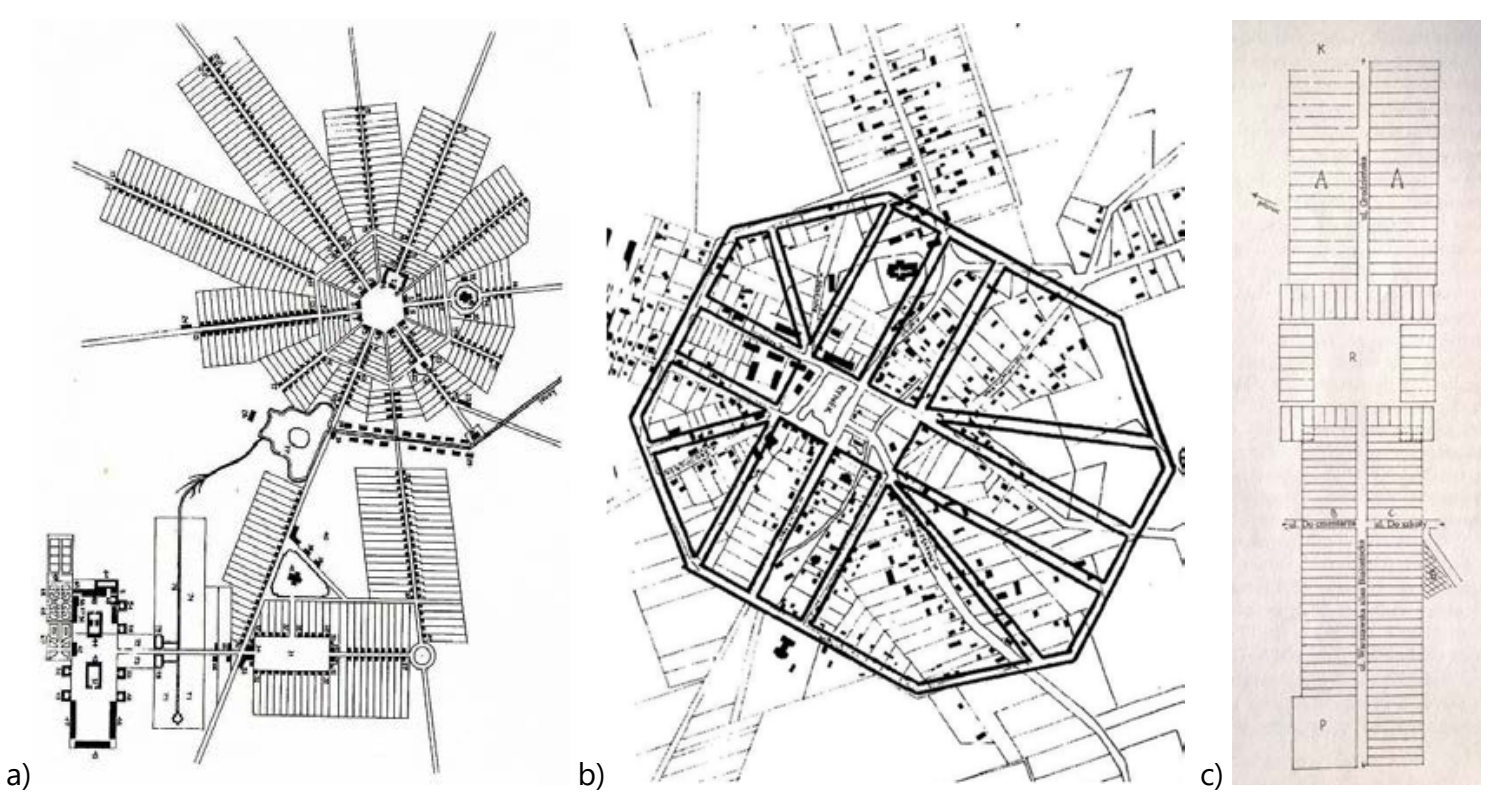

Ryc. 1. Teoretyczne plany miejscowości: a)plan Krynek z 1780r. (Józef de Sacco) [5, s. 46], b)teoretyczny plan Dąbrowy Białostockiej (oprac. K. Glapińska) [5, s. 43], c) rekonstrukcja planu Sokółki (oprac. P. Borowik) [6, s. 34]

Historię założenia dworsko-ogrodowego w Krynkach opisali na bazie zachowanych materiałów źródłowych Ewa Bończak-Kucharczyk i Józef Maroszek ${ }^{11}$. Kompleks ów stanowił istotny element kompozycji przestrzennej miejscowości, jednak na skutek zniszczeń i degradacji po II wojnie światowej stracił na czytelności, a o jego wcześniejszym istnieniu świadczą jedynie skupiska drzew i przykościelna barokowa brama zwrócona w kierunku dawniej istniejącego założenia.

9 P. Borowik, Rozplanowanie miasteczek..., s. 44-48.

10 T. P. Szafer, s. 53; Plan z końca XIX w. wskazuje zmiany w geometrii układu urbanistycznego oraz lokalizacji obiektów: synagogi, która nie została powiązana osiowo z rynkiem oraz hal targowych przesuniętych z narożnika rynku do jego centrum. Na planie nie wskazano lokalizacji ratusza. Brakuje także widocznej na rysunku de Sacco ulicy obwodowej, która dawałaby czytelne granice przestrzenne w krajobrazie tej części Krynek.

11 E. Bończak-Kucharczy, J. Maroszek, http://www.testowy.minigo.pl/index.php/page/krynki (dostęp 10.2016) 
Rekonstrukcja układu przestrzennego Dąbrowy Białostockiej z końca XVIII wieku wzbudziła dyskusję. Przemysław Borowik zajął polemiczne stanowisko w stosunku do opracowanego przez Krystynę Glapińską teoretycznego planu Dąbrowy z czasów Antoniego Tyzenhauza ${ }^{12}$. Autorka rysunku przedstawiła koncepcję schematu promienistego rozplanowania czternastu ulic odchodzących od rozległego prostokątnego rynku, spiętych ośmioboczną ulicą obwodową, wrysowaną na podkładzie współczesnego planu miejscowości, wykazując iż część kierunków i kształtów geometrii współczesnej tkanki urbanistycznej pokrywa się z jej hipotezą. Rysunek wskazuje na inspirację koncentrycznymi planami miast idealnych w koncepcji założenia kompozycji urbanistycznej Dąbrowy. P. Borowik krytycznie podchodzi do liczby i kształtu ulic wrysowanych przez K. Glapińską, wykazując, że część z nich nie istniała ${ }^{13}$. Przywołuje także dwie cechy istotne kompozycyjnie: lokalizację dawnej, nieistniejącej obecnie cerkwi w okolicach rynku oraz powiązanie tyzenhauzowskiej przebudowy z istniejącą wcześniej ulicówką, której główną dominantą był kościół.

Historię Sokółki wraz z analizą zachowanych dokumentów dotyczących działalności Antoniego Tyzenhauza oraz zatrudnianego przez niego architekta Józefa de Sacco w postaci monografii spisał Leszek Postołowicz ${ }^{14}$. Rekonstrukcję planu miasteczka natomiast opracował Przemysław Borowik ${ }^{15}$. Z jego pracy dowiadujemy się o głównych elementach przebudowy Sokółki planowanej i częściowo przeprowadzonej pod koniec XVIII w. Nowy kształt przestrzenny miejscowości bazował na osiowej kompozycji ulic Grodzieńskiej i Warszawskiej (Białostockiej), które symetrycznie dzieliły rozległy kwadratowy rynek. Wokół głównego placu miejskiego i wzdłuż ulic wyznaczono regularne prostokątne działki, których rozłożenie podkreślało symetrię i osiowość całej kompozycji urbanistycznej. Przy odbudowie Sokółki miały być wykorzystane projekty modelowe zarówno planów urbanistycznych jak i pojedynczych budowli ${ }^{16}$.

Ewa Bończak-Kucharczyk i Józef Maroszek opisali natomiast historię założenia pałacowo-ogrodowego stanowiącego siedzibę administracji królewskiej ${ }^{17}$. Jej początkiem był projekt ",Planty Zabudowania Gubernji J.K.Mci Sokolskiey", którego autorstwo, podobnie jak w Krynkach, przypisuje się Józefowi de Sacco ${ }^{18}$. Założenie zaplanowane z dużym rozmachem, który nota bene zarzucano Tyzenhauzowi, nie przetrwało do czasów współczesnych.

\section{Współczesny krajobraz miejscowości}

Wyniki współczesnej analizy krajobrazu miasteczek wskazują na zachowanie czytelności fragmentów kompozycji urbanistycznej z końca XVIII wieku. Widoczne są one pomimo wprowadzenia korekty koncepcji planów wzorowanych na miastach idealnych do warunków zróżnicowanej rzeźby terenu. Istotę układu przestrzennego potwierdzają lokalizacje obiektów architektonicznych dominat. Budowle wzniesione w kolejnych epokach po Tyzenhauzie, usytuowane w miejscach wskazanych kompozycją, potwierdzają jej walory i logikę porządku przestrzennego. Powstałe $w$ ten sposób nawarstwienia utrwalają tożsamość $\mathrm{i}$ budują indywidualny kod genetyczny przestrzeni miasteczek.

Na uwagę zasługuje lokalizacja obiektów kultowych w kontekście osiemnastowiecznych planów miejscowości. Dominaty zostały powiązane osiami widokowymi ze strukturą przestrzenną miejscowości i są widoczne $z$ wielu punktów ich przestrzeni.

W Krynkach cerkiew zamyka kompozycyjnie oś widokową ulicy odchodzącej od narożnika rynku. Kościół położony po drugiej stronie doliny w stosunku do centralnego rynku, jest widoczny w zamknięciu osi widokowych dwóch ulic z rynkiem powiązanych. W tym wypadku lokalizacja miejscowości na obu wyniesionych brzegach rzeki Krynki, pozwoliła uzyskać efekt kompozycyjny, który nie wynikał wprost z planu Józefa de Sacco.

12 P. Borowik, Rozplanowanie miasteczek..., s. 42-43; Autor przywołuje opracowanie oraz zamieszcza teoretyczny rysunek planu Dąbrowy Białostockiej autorstwa Krystyny Glapińskiej.

13 ibidem, s. 42

14 L. Postołowicz, Sokótka i okolice, s. 17-23, 99-105

15 P. Borowik, Rozplanowanie Sokótki..., s. 21-34

16 ibidem, s. 32

17 E. Bończak-Kucharczyk, J. Maroszek ; http://www.testowy.minigo.pl/index.php/page/sok-ka (dostęp 10.2016)

18 T. Sulerzycka, Katalog rysunków z Gabinetu Rycin Biblioteki Uniwersyteckiej w Warszawie, cz. 2, Miejscowości różne. Rysunki architektoniczne dekoracyjne. Plany i widoki z XVIII i XIX wieku, Warszawa 1969, s. 187, nr 817; M. Kwiatkowski, Stanisław August. Król-Architekt, wyd. Ossolineum, Warszawa 1983 
Uzyskano wartość dodaną, która wzmocniła walory krajobrazowe miejscowości w stosunku do schematu wzorowanego na planie miasta idealnego.

a)
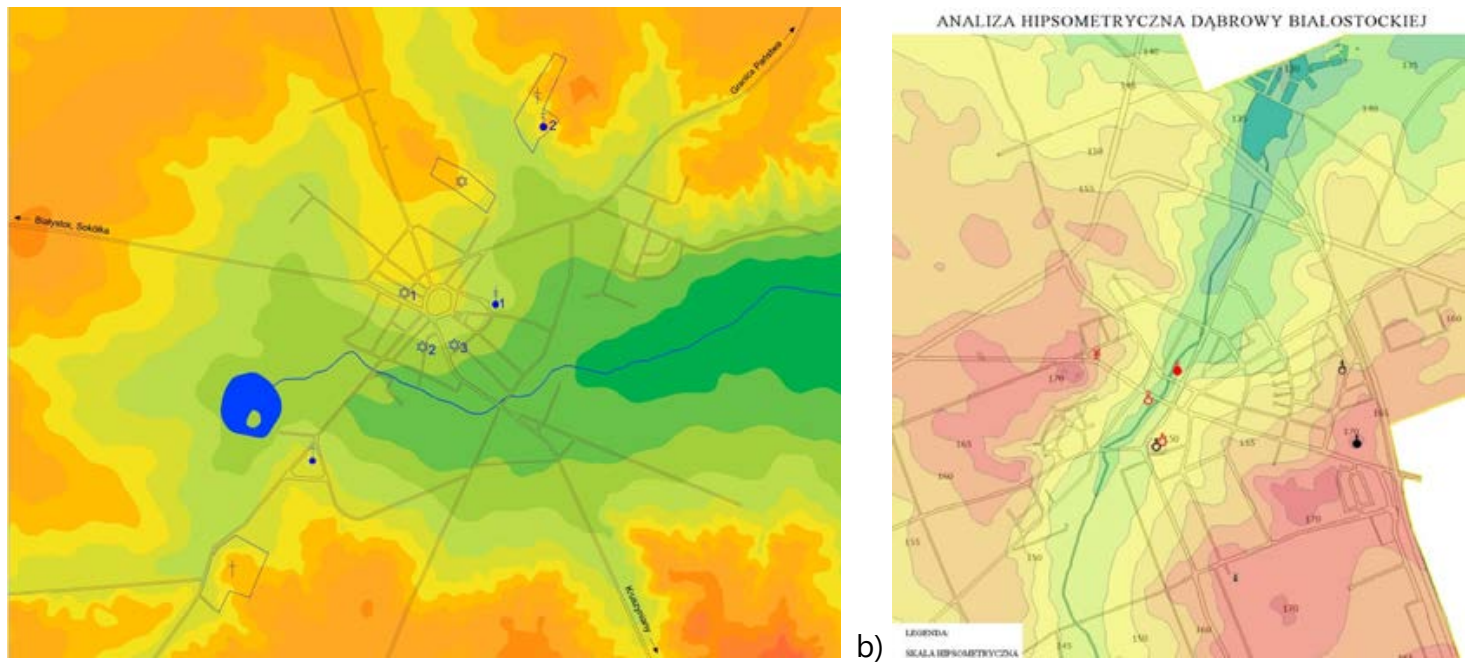

Ryc. 2. Analiza dostosowania zgeometryzowanego układu miast do topografii terenu: a) Krynki (oprac. A. Kosacka-Nalewajko) [9], b)Dąbrowa Białostocka (oprac. U. Peliksza)[13].

a)

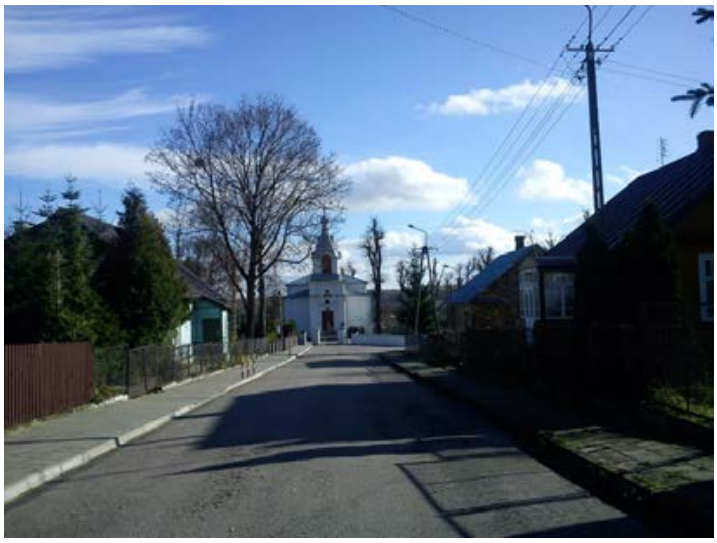

b)
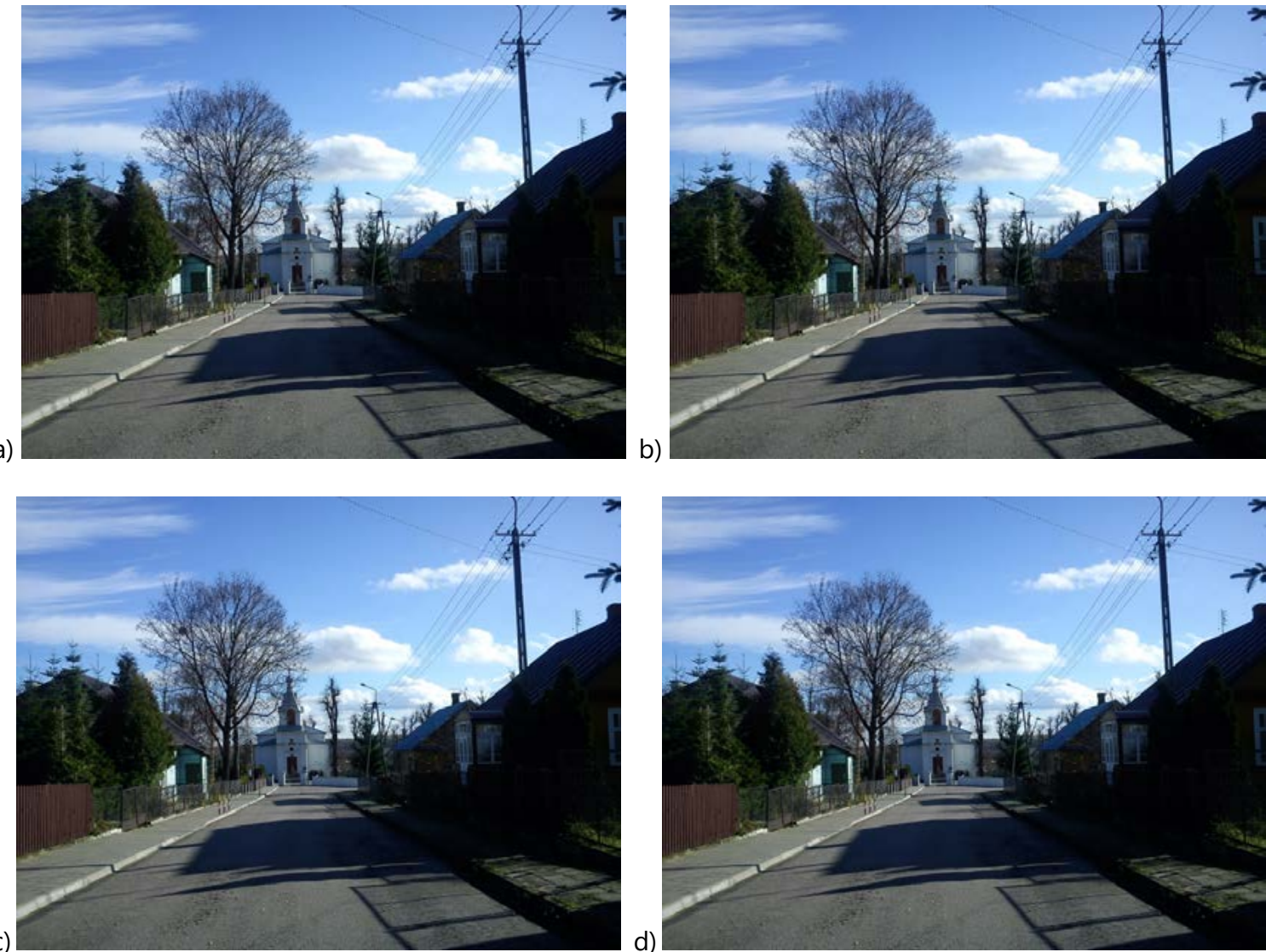

d)

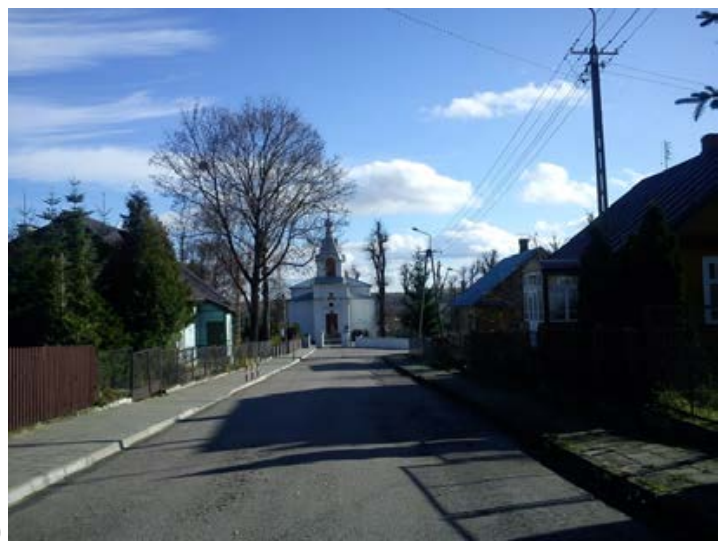

Ryc. 3. Powiązania widokowe w przestrzeni miejscowości: a) widok cerkwi w Krynkach, b) widok kościoła w Krynkach, c) widok cerkwi w Dąbrowie, d) otwarcie krajobrazowe z rynku w Sokółce (wszystkie fot. D. Gawryluk, 2013-2016) 
W Dąbrowie Białostockiej lokalizacja współcześnie wzniesionej cerkwi została powiązana ze strukturą osiemnastowieczną w dwojaki sposób: po pierwsze świątynia została wybudowana w sąsiedztwie zachowanego fragmentu wielobocznej ulicy obwodowej, po wtóre zaś jej lokalizacja zamyka osiowo widok skierowany ponad miasteczkiem od strony wjazdu z Suchowoli. Przebieg osi widokowej tylko częściowo jest potwierdzony w strukturze urbanistycznej, ale rozłożenie miejscowości po dwóch stronach doliny zapewniło czytelność ekspozycji budowli w panoramie miejscowości.

Cerkiew wybudowana przez władze carskie na pocz. XX w. jest dominantą architektoniczną przestrzeni rynku Sokółki, nie ma natomiast powiązań widokowych z miejscowością ze względu na usytuowanie przesunięte w stosunku do przebiegu ulicy dzielącej rynek na dwie symetryczne części. W przypadku Sokółki szczególnym walorem jest dalekie, osiowe otwarcie krajobrazowe skierowane z rynku na zewnątrz, zgodnie z przebiegiem ul. Białostockiej. W tym wypadku jest ono skutkiem wytyczenia placu na wzniesieniu górującym nad otaczającą go częścią miasta.

Niedostatek współczesnego krajobrazu badanych miast stanowi zatarcie lub częściowa utrata czytelności przestrzeni rynku w strukturze ośrodków. Jedynie w Sokółce główny plac miejski ma zwartą formę określoną granicami czytelnych pierzei. Niedogodność w tym wypadku stanowi tranzytowy ruch prowadzony przez główną ulicę tnącą osiowo rynek. Intensywny ruch samochodowy stanowi niemal trwałą granicę w przestrzeni placu, a zlokalizowany w jednej połowie park utrudnia jego czytelność w kierunku poprzecznym.

Czytelność przestrzenna dawnego rozległego rynku z końca XVIII wieku w Dąbrowie Białostockiej jest tylko fragmentaryczna. Część jego powierzchni została zapełniona zabudową oraz parkiem miejskim. Wydłużony prostokąt placu został zredukowany do zwartych proporcji bliskich kwadratowi, jednak relikty dawnych granic rynku można odczytać w przebiegu ulic i kwartałów współcześnie z nim sąsiadujących.

Największa destrukcja czytelności przestrzeni rynku zaszła w Krynkach. Sześcioboczny plac został zredukowany do wielokierunkowego ronda z parkiem miejskim usytuowanym na rozległej wyspie "obwodowego skrzyżowania". Przestrzeń o historycznie zdefiniowanej formie i funkcji, współcześnie została zredukowana do kłopotliwego (ze względu na liczne zjazdy) węzła komunikacyjnego z wyspą zieleni wewnątrz. Obszar ów nawet przez mieszkańców przestał być identyfikowany jako plac. Najbardziej charakterystyczny element kompozycji urbanistycznej z końca XVIII wieku stracił na znaczeniu i czytelności w krajobrazie miejscowości.

Zatarciu w strukturze przestrzennej miejscowości uległa lokalizacja rozległych założeń dworsko-ogrodowych przewidzianych na siedziby administracji guberni. Po Il wojnie światowej uległy one dewastacji, zmieniono ich przeznaczenie lub zabudowano osiedlami mieszkaniowymi.

\section{Podsumowanie}

Korekta, której poddano pod koniec XVIII w. teoretyczne plany Krynek, Dąbrowy i Sokółki, wynikała z dostosowania do topografii terenu. Zracjonalizowanie ich schematów, koncepcyjnie powiązanych z planami miast idealnych, spowodowało uzyskanie wartości dodanej, polegającej na widokowym wpisaniu dominant architektonicznych - świątyń w krajobraz miejscowości. Dostosowanie zgeometryzowanych planów do zastanych warunków zróżnicowanego ukształtowania terenu, w przeciwieństwie do licznych negatywnych ocen mówiących o odstępstwach od regularności rysunku, w ocenie autorki wpłynęło na uzyskanie korzystnych, indywidualnych cech krajobrazowych struktury badanych miejscowości.

Zachowana częściowa czytelność XVIII-wiecznej kompozycji urbanistycznej miasteczek stanowi ich istotną wartość kulturową, budującą nadal tożsamość krajobrazową miejscowości, stanowiącą ich szczególny wyróżnik na tle miasteczek regionu i potwierdzają swoisty kod genetyczny ${ }^{19}$.

19 Z. Zuziak, s. 52; Zbigniew K. Zuziak przywołuje J. P. Kleihuesa i teorię Rossiego, w której "Myślenie o przestrzeni miejskiej w kategoriach architektury miasta jest poszukiwaniem racjonalności struktury urbanistycznej". W przypadku Aldo Rossiego jest to traktowanie formy urbanistycznej jako pewnej całości posiadającej swój „kulturowy kod genetyczny”, dualizm pojęć „materia ponadczasowa” i „cykliczna reinterpretacja". Tkanka miejska należy do najsilniejszych wyznaczników miasta, jest cechą morfologiczną, pozwala na poszukiwanie wielości nawarstwionych znaczeń całościowego kolażu, jak i klasycystycznego trendu nadającego tej całości pewien porządek. Te nawarstwienia w krajobrazie wymagają przeprowadzenia badań zachowania czytelności budującej tożsamość architektoniczno-urbanistyczną miejscowości. 


\section{Piśmiennictwo}

[1] Bach J. S., (red.), Krynki 500 lat, Krynki 2009

[2] Benevolo L., Miasto w dziajach Europy, Warszawa1995

[3] Bończak-Kucharczyk E., Maroszek J., Krynki-park dworski, http://www.testowy.minigo.pl/index.php/page/krynki [dostęp: październik 2016]

[4] Bończak-Kucharczyk E., Maroszek J., Sokótka - park dworski, http://www.testowy.minigo.pl/index.php/article/show/ id/203 [dostęp: październik 2016]

[5] Borowik P., Ile miasteczek naprawdę istniało w ekonomii grodzieńskiej w okresie zarządu Antoniego Tyzenhauza?, [w:] Małe Miasta. Historia I Współczesność, M. Zemło (red.) Supraśl 2001, tom I, s. 75-79

[6] Borowik P., Rozplanowanie miasteczek ekonomii grodzieńskiej w czasach Antoniego Tyzenhauza, [w:] Małe Miasta. Przestrzenie, M. Zemło (red.) Supraśl 2003, tom III, s. 35-50

[7] Borowik P., Rozplanowanie I zabudowa Sokótki w XVII-XVIII wieku, [w:] Małe Miasta. Między Tradycją a Wyzwaniem Przeszłości, M. Zemło (red.) Supraśl 2002, tom II, s. 21-34

[8] Ciołek G., Ogrody polskie, Warszawa 1978, ryc. 135

[9] Dobroński A. Cz., Miasta województwa podlaskiego, Białystok 2014

[10] Kosacka-Nalewajko A., Aktywizacja turystyczna Krynek, magisterska praca dyplomowa zrealizowana na kierunku Gospodarka przestrzenna, pod opieką promotorską dr inż. arch. D. Gawryluk, dostępna w Archium Prac Dyplomowych Politechniki Białostockiej, Białystok 2016

[11] Kostof S., The City Shaped. Urban Patterns and Meanings Throuhg History, London 1991

[12] Kwiatkowski M., Stanisław August. Król-Architekt, wyd. Ossolineum, Warszawa 1983

[13] Paszkowski Z., Miasto idealne w perspektywie europejskiej i jego związki z urbanistyka współczesna, Kraków 2011

[14] Peliksza U., Aktywizacja turystyczna Dąbrowy Białostockiej, magisterska praca dyplomowa zrealizowana na kierunku Gospodarka przestrzenna, pod opieką promotorską dr inż. arch. D. Gawryluk, dostępna w Archium Prac Dyplomowych Politechniki Białostockiej, Białystok 2014

[15] Słodczyk J., Historia planowania i budowy miast, Opole 2012

[16] Spostołowicz L., Sokótka I okolice. Przyczynki do dziejów miasta I powiatu, Sokółka 2009

[17] Sulerzycka T., Katalog rysunków z Gabinetu Rycin Biblioteki Uniwersyteckiej w Warszawie, cz. 2, Miejscowości różne. Rysunki architektoniczne, dekoracyjne. Plany i widoki z XVIII i XIX wieku, Warszawa 1969, s. 187, nr 817

[18] Szafer T. P., Ze studiów nad planowaniem miast w Polsce XVIII i pocz. XIX w., [w:] Studia z Historii Budowy Miast,Warszawa 1955, s. 47-82

[19] Szkiłądź M., Dąbrowa Biaostocka - wiatrak holenderski, [w:] Biuletyn Konserwatorski Województwa Podlaskiego, Białystok 2003, z. 8-9.2003, s. 271-274

[20] Szpakowska E., Architektura miasta idealnego. Wprowadzenie. Architecture of ideal city. Introduction, [w:] Przestrzeń i Forma. Space and Form, 16/2011, s. 121-154 http://www.pif.zut.edu.pl/pl/pif16---2011/ (dostęp 10.2016)

[21] Wiśniewski J., Osadnictwo wschodniej białostocczyzny. Geneza, rozwój oraz zróżnicowanie I przemiany etniczne, [w:] Acta Baltico-Slavica, t. 11, Wrocław 1977, s. 7-80

[22] Wróbel T., Zarys historii budowy miast, Wrocław-Warszawa-Kraków-Gdańsk 1971

[23] Zuziak Z. K., O tożsamości urbanistyki, Kraków 2008

\section{Ryciny}

[24] Ryc. 1. Teoretyczne plany miejscowości: a) plan Krynek z 1780r. (Józef de Sacco) [5, s.46], b) teoretyczny plan Dąbrowy Białostockiej (oprac. K. Glapińska [5, s. 43]), c) rekonstrukcja planu Sokółki (oprac. P. Borowik)[6, s. 34]

[25] Ryc. 2 Analiza dostosowania zgeometryzowanego układu miast do topografii terenu: a) Krynki (oprac. A. Kosacka-Nalewajko) [9], b)Dąbrowa Białostocka (oprac. U. Peliksza)[13]

[26] Ryc. 3. Powiązania widokowe w przestrzeni miejscowości: a)widok cerkwi w Krynkach, b) widok kościoła w Krynkach, c) widok cerkwi w Dąbrowie, d)otwarcie krajobrazowe z rynku w Sokółce (wszystkie fot. D. Gawryluk, 2013-2016) 


\section{Tyzenhauz's towns - certificate of 18th towns's spatial culture in their contemporary townscape (Krynki, Dąbrowa Białostocka, Sokółka)}

Summary: Antoni Tyzenhauz's (Lithuanian treasurer from times of Stanisław Augusta and the Hrodna district administrator) activity at the end of the 18th century was aimed on economic activation of north-eastern part of Rzeczpospolita. About 50 manufactories were made near Hrodna from his initiative. Important effect of Tyzenhauz's activity was also change of spatial form of choosen towns (among others Krynki, Dąbrowa Białostocka, Sokółka). Small towns had regular plans with geometrical urban planning composition. Elements of spatial culture from the end of 18th century survived apart of their dificult history. They are important features of towns'es contemporary identity now. The article is devoted to legibility of the historical composition from the end of the 18th century in the contemporary townscape of Krynki, Dąbrowa Białostocka i Sokółka.

Key words: Tyzenhauz's towns, Krynki, Dąbrowa Białostocka, Sokółka, townscape 